\title{
The phytochemistry and medicinal value of Psidium guajava (guava)
}

\author{
Sumra Naseer ${ }^{1}$, Shabbir Hussain ${ }^{1 *} \mathbb{D}$, Naureen Naeem², Muhammad Pervaiz ${ }^{3}$ and Madiha Rahman ${ }^{4}$
}

\begin{abstract}
Psidium guajava (guava) is well known tropic tree which is abundantly grown for fruit. Many countries have a long history of using guava for medicinal purposes. This plant finds applications for the treatment of diarrhea, dysentery, gastroenteritis, hypertension, diabetes, caries and pain relief and for improvement in locomotors coordination. Its leaf's extract is being used as a medicine in cough, diarrhea, and oral ulcers and in some swollen gums wound. Its fruit is rich in vitamins A, C, iron, phosphorus and calcium and minerals. It contains high content of organic and inorganic compounds like secondary metabolites e.g. antioxidants, polyphenols, antiviral compounds, anti-inflammatory compounds. The phenolic compounds in guava help to cure cancerous cells and prevent skin aging before time. The presence of terpenes, caryophyllene oxide and $p$-selinene produces relaxation effects. Guava leaves contain many compounds which act as fungistatic and bacteriostatic agents. Guava has a high content of important antioxidants and has radio-protective ability. Quercetin is considered as most active antioxidant in the guava leaves and is responsible for its spasmolytic activity. Its ethyl acetate extract can stop the germ infection and thymus production. Guava possesses anti-viral, anti-inflammatory, anti-plaque and anti-mutagenic activities. Guava extract shows antinociceptive activity and is also effective in liver damage inflammation and serum production. Ethanolic extract of guava can increase the sperm quality as well as quantity and can be used for the treatment of infertile males.
\end{abstract}

Keywords: Psidium guajava, Medicinal, Antimicrobial, Anti-inflammatory, Anti-oxidant

\section{Background}

Psidium guajava (common name-guava) is well known tropic tree which is abundantly grown for fruit. It belongs to phylum Magnoliophyta, class Magnoliopsida and Myrtaceae family [1]. It has about 133 genera and more than 3,800 species. Psidium guajava and it's all parts have an old history of medicinal value [2]. The plant is well known by a common name "Guava" in English, guayabo in Spanish, goyaveandgoyavier in French, guyabaorgoeajaab in Dutch, goiaba and goaibeira in Portuguese and jambubatu in Malaya. Pichi, posh and enandi are the names commonly used in Mexico and America [3]. Guava plant grows widely in the tropic areas because it is a plant that can be grown on a big range of soils [4]. In Mexico guava is one of very important crop which is cultivated over 36,447 acres and production is about 192,850 tons. According to records the

\footnotetext{
*Correspondence: shabchem786@gmail.com; dr.shabbirhussain@lgu.edu.pk ${ }^{1}$ Department of Chemistry, Lahore Garrison University, DHA Phase VI, Lahore, Pakistan

Full list of author information is available at the end of the article
}

first money-making guava planting was reputable around 1912 in Florida at Palma Sola [3].

Psidium guajava is an evergreen shrub like tree which reaches to the height of 6 to $25 \mathrm{ft}$ 's. Figure 1 displays various parts of the plant i.e., leaves, flowers, fruit, seeds and bark.

The plant has a wide spreading network of branches. Mostly its branches are curved which display opposite leaves with the small petioles of about 3 to $16 \mathrm{~cm}$. The leaves are wide and clear green in color and have clear and prominent veins $[5,6]$. The plant produces white flowers with incurved petals having a nice fragrant. Flowers have four to six petals and yellow colored anthers and pollination occurs by the insects. Guava fruit ranges from small to medium sized with 3 to $6 \mathrm{~cm}$ length. It has pear like shape and yellow color in ripen condition [7]. It has a musky special odor when ripened which is strong but pleasant [3]. Its pulp is slightly darker in color which contains slightly yellowish seeds. The size of seeds is very small and they are easily chewable. They are arranged in regular patterns; their number 


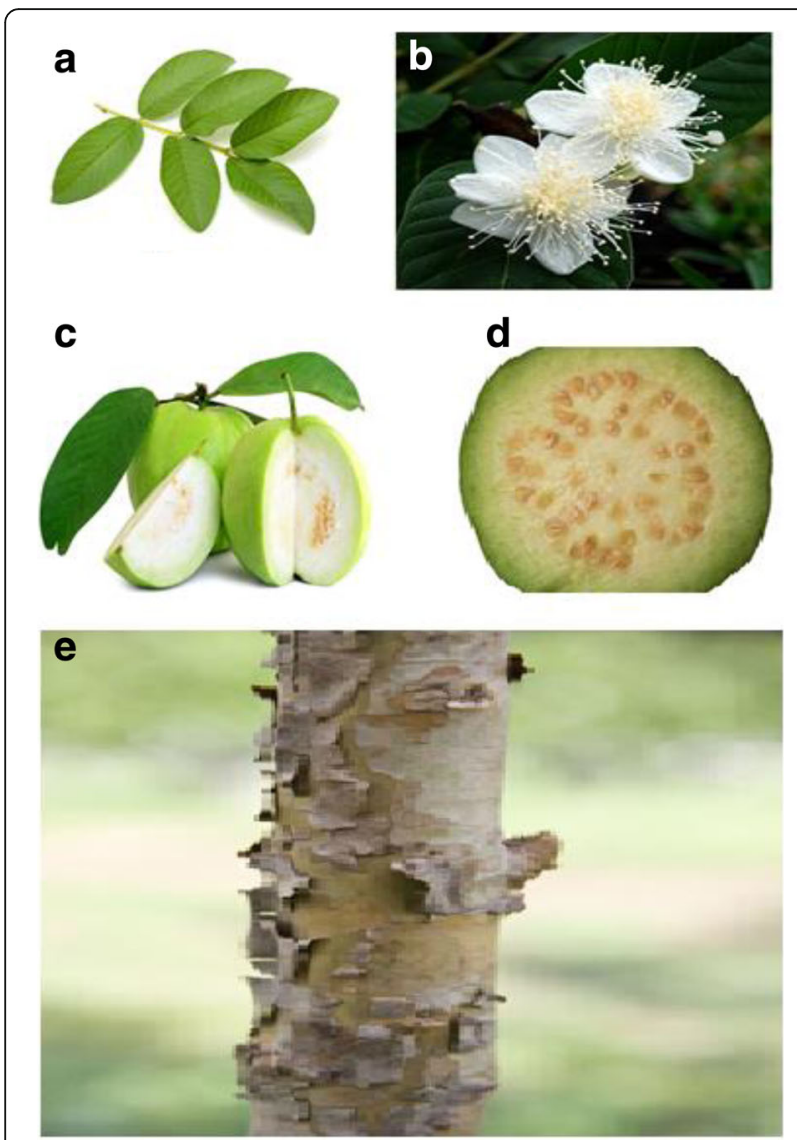

Fig. 1 Various parts of guava (a) Leaves (b) Flowers (c) Fruit (d) Seeds in the fruit (e) Bark

ranges from 112 to $535[3,8]$. The guava bark is thin and has green colored spots. It is very easy to remove it in long straps. It has a huge content of antimicrobial and antibacterial compounds [9]. Ethanolic extracts of stem have a high anti-diabetic activity $[10,11]$. Guava contains a large number of antioxidants and phytochemicals including essential oils, polysaccharides, minerals, vitamins, enzymes, and triterpenoid acid alkaloids, steroids, glycosides, tannins, flavonoids and saponins [12]. Guava contains a higher content of vitamin $\mathrm{C}$ and vitamin $\mathrm{A}$. Guava is also a very good source of the pectin which is an important dietary fiber. It has high content of flavonoids [7], fructose sugar [13] and carotenoids [14]. Keeping in view the historical background, important ingredients and common uses of Psidium guajava (guava), current studies focus on the phytochemistry and medicinal value of this useful plant.

\section{Chemical composition of guava}

The guava fruit contains vitamin A, C, iron, phosphorus and calcium. It has more vitamin $\mathrm{C}$ than the orange. The fruit contains saponin, oleanolic acid, lyxopyranoside, arabopyranoside, guaijavarin, quercetin and flavonoids $[5,7$,
15]. Ascorbic acid and citric acid are the major ingredients of guava that play important role in anti-mutagenic activity [16]. The chemical structures of quercetin and ascorbic acid have been shown in Fig. 2 .

The skin of fruit contains ascorbic acid in very high amount; however, it may be destroyed by heat. The strong pleasant smell of fruit is credited to the carbonyl compounds [15]. Guava fruit contains terpenes, caryophyllene oxide and p-selinene in large quantity which produce relaxation effects [17]. The flavonoid content is higher in the methanolic extract of the guava [18]. There are 41 hydrocarbons 25 esters, 13 alcohols and 9 aromatic compounds in guava [19]. Titratable acidity and the total soluble solids are present in fruit [20]. Guajadial is also present in guava [21].

Essential oil is present in leaves which contain $\alpha$-pinene, limonene, $\beta$-pinene, isopropyl alcohol, menthol, terpenyl acetate, caryophyllene, longicyclene and $\beta$-bisabolene. Oleanolic acid is also found in the guava leaves [22]. Leaves have high content of limonene about $42.1 \%$ and caryophyllene about $21.3 \%$ [23]. Leaves of guava have a lot of volatile compounds [24, 25].

The bark includes $12-30 \%$ of tannin and one source declares that it includes tannin $27.4 \%$, or polyphenols, resin and the crystals of calcium oxalate. Tannin is also

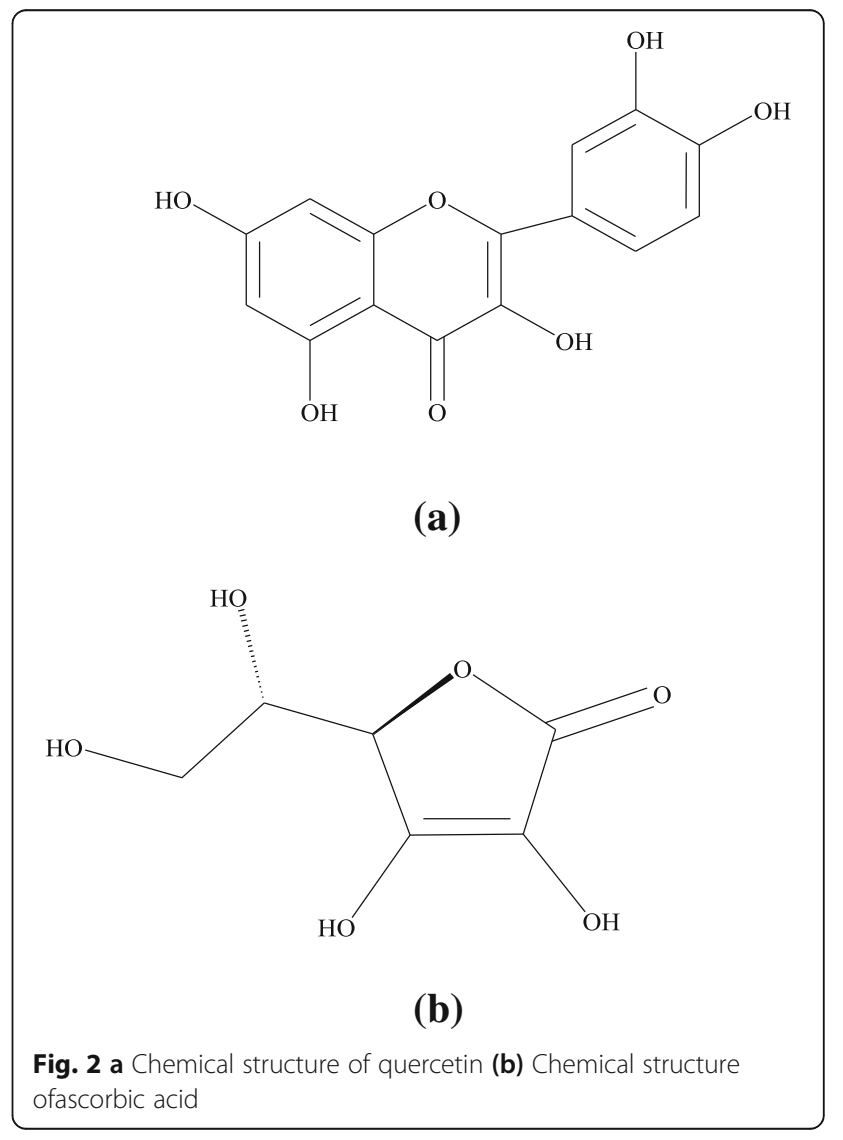


present in roots. Leukocyanidins, gallic acid and sterols are also present in roots. Carbohydrates with salts are present in abundance. Tannic acid is also its part.

\section{Medicinal importance of guava}

Psidium guajava L. is consumed not only as food but also as folk medicine in subtropical areas all over the world due to its pharmacologic activities [26]. Medicinal plants find a very important place in medical systems almost in the entire world. These observations are reflected from traditional knowledge. It is well known that guava is frequently employed in numerous parts of the world for the cure of a lot of sickness like diarrhea reducing fever, dysentery, gastroenteritis, hypertension, diabetes, caries, pain relief and wounds. The countries which have a long history of using medicinal plants are also using guava at big level like Mexico, Africa, Asia and Central America. With its medicinal uses it is also used as food and in the preparation of food products. It is also used in house construction and toys making. Guava contains high content of organic and inorganic compounds like secondary metabolites e.g. antioxidant, polyphenols, antiviral compounds and anti-inflammatory compounds. Guava has a lot of compounds which have anti cancerous activities. It has a higher number of vitamins and minerals. Phenolic compounds like flavonoids also find an important place in the guava. Lycopene and flavonoids are important antioxidants. They help in the cure of cancerous cells and help to prevent skin aging before time [27]. Guava can affect the myocardium inotropism [28]. Guava skin extract can control level of diabetes after 21 days treatment [29].

\section{Antimicrobial activity}

Guava has a high antimicrobial activity. Guava leaf's extract doses can reduce the amount of cough due to its anti-cough activity. Aqueous, chloroform and methanol extract of leaves can reduce the growth of different bacteria. Due to its anti-cough activity it is recommended in the condition of cough [30].

Guava leaves have high antibacterial activity in extracts that can inhibit the growth of $S$. aureus. Plant leaf and bark methanolic extracts of P. guajava have high antimicrobial activity. These extracts can inhibit the Bacillus and Salmonella bacteria [31]. Methanolic extract of guava contains a remarkable antimicrobial activity. Species of Bacillus and Salmonella bacteria can be controlled by these extracts. It also has anti-plaque activity due to the presence of active flavonoids compounds [32].

The flavonoid compounds and their derivatives can be isolated from the guava. These compounds can inhibit the growth of different bacteria in different dilutions. Terpinene and pinene are present into the aqueous extract of plant's leaves which shows antimicrobial activity.
Due to bacteriostatic effects on pathogenic bacteria it is also used as medicine in cough, diarrhea, oral ulcers and in some swollen gums wound $[1,33]$.

Aqueous and ethanol extracts show low antimicrobial activity or minimum inhibitory concentration (MIC) whenever methanol extract shows high MIC. Due to it high activity methanolic extract is most effective. This extract also displays anti hemolytic potential as it shows activity against hemolysis [34]. The antibacterial activity of guava is high against gram positive bacteria and moderate against the gram negative bacterial strains [35]. In 2012 it was reported that guava leaves have many compounds which act as fungistatic and bacteriostatic agents. They can stop the growth of a lot of bacteria and act as anti-viral agents. They can control the viral infections like influenza virus. They can hold and occupy the viral resistance. The actual reason of guava anti-viral activity is protein degradation ability of the guava extract [36]. Essential oil of guava also has activity against the Salmonella and S. aureus [37]. Guava also possesses anticancer and antioxidant activities. There are a lot of compounds like Gallic acid, galangin, kaempferol, homogentisic acid and cyanidin 3-glucoside which are found in peels, seeds and pulp of guava. But it is surprising that the amount of these compounds is high in seeds and skin as compared to the pulp. Due to the presence of these compounds guava's food importance becomes high [38]. It is very clear that aqueous and methanol extract of the guava leaves inhibit the growth of bacteria and can produce a remarkable zone of inhibition. The extracts in methanol and water show maximum MIC whenever ethanol extract shows minimum anti-fungal activity. Conclusively leaves, seeds, skin and pulp of guava have a remarkable anti-microbial activity [39].

The antimicrobial activities of alcohol fruit extracts from guava (Psidium guajava) were compared to those of pineapple (Ananas comosus) and apple (Malus pumila). Eight bacterial strains including Pseudomonas aeruginosa, Klebsiella, Enterococcus faecalis, Shigella flexineri, Enterobacter cloacae, Enterotoxigenic E.coli (ETEC), Enteroaggregative E.coli (EAEC) and Staphylococcus aureus were used for antimicrobial evaluations. The fresh fruits of the above mentioned plants were purchased from the market; then they were cut into small cubes and finally dried over 4-5 days in sun to a crisp. The pieces were blended to the fine powder; finally methanol extracts were obtained by passing $75 \mathrm{~g}$ of each powder through a Soxhlet apparatus having $250 \mathrm{ml}$ of 99\% methanol. The same process was performed with $250 \mathrm{ml}$ of ethanol to produce a methanolic crude extract. The sample extracts were evaluated using agar well diffusion method. Norfloxacin and water were used as positive and as negative controls, respectively. The extracts caused the inhibition of microbes; the zones of 
inhibition were measured and an activity index was calculated from the mean zone sizes. It was concluded that all the fruits possess some antimicrobial potential; the highest activity index (2.6) was observed from pineapple extracts against $E A E C$. The pineapple fruit displayed strong potential against all the bacteria. The guava extracts possessed the antimicrobial potential against all the microbes with the exception of ETEC. The methanolic and ethanolic extracts of apple were found active only against EAEC And Staph. Aureus. The methanolic extracts of guava and apple were found active as compared to the ethanolic extracts while the ethanolic extracts of pineapple showed slightly larger inhibition zones. The results of this investigation show great promise for potential antimicrobial drugs [40].

The antimicrobial potential of guava can be compared to that of similar commonly used fruit like pomegranate which have been found to possess high antimicrobial properties [41]. The antimicrobial activity of various extracts prepared from pomegranate fruit peels were evaluated using both in-vitro agar diffusion and in-situ methods against some food-borne pathogens. It was found that $80 \%$ methanolic extract of peels was a potent inhibitor for Yersinia enterocolitica, Listeria monocytogenes, Staphyllococcusaureus and Escherichia coli. And the presence of active inhibitors in peels including phenolics and flavonoids were revealed by phytochemical analysis as potent constituents. The study suggested that the various extract of pomegranate can successfully control various kinds of human pathogenic bacteria [42].

There is a growing trend to use the medicinal plants as the natural resources in order to develop new drugs. The natural products are applied to treat various viral, fungal and bacterial diseases. The genus citrus is well known for its pharmaceutical importance. The peel extracts of Dargiling Orange (C8), South African Malta (C5), Kagja Lemon (C2), Batabi Lemon (C4), Elachi Lemon (C3), Kagja Lemon (C2) and Kagji Lemon (C1) show excellent antimicrobial potential against various bacterial strains e.g., B. cereus, S. aureus etc [43]. The antimicrobial activities of peels extract of two Citrus fruits viz., Citrus aurantium and Citrus sinensis were evaluated. The peels of the fruits were separated, shade dried, powdered and extracted using methanol; finally the peel extracts were subjected to test their antifungal and antibacterial activities by poisoned food technique and agar well diffusion assay, respectively. The extracts were found effective against the tested fungal and bacterial strains. It was concluded that the peel extracts of selected citrus fruits can be used to control anthracnose of chilli caused by C. capsici and against infectious agents [44]. Eating fruits is very important to reduce the pressure of antibiotics; the fruits are also relatively cheaper and readily available and could greatly help the people [40].

\section{Antidiarrheal activity}

Diarrhea is one of most common and well recognized health problem and a global issue. It is very common even in developed countries. It is estimated that about 2.2 million people die annually by diarrhea; most of them, are children or infants [45].

Guava leaves have quercetin-3-arabinoside and quercetin which can be isolated from leaves. Its leaves contain a compound which has morphine like action. It controls the muscular tone. Quercetin repressed intestinal contraction encouraged by enhanced absorption of calcium. Quercetin has a strong effect on ileum. It is thought that quercetin in guava leaf are responsible for its spasmolytic activity. Guava has high cytotoxicity [46]. Guava can be used to treat the diarrhea caused by the $E$. coli or S. aureus toxins [47]. Ethanolic and aqueous extracts of Psidium guajava at a concentration of $80 \mathrm{~g} / \mathrm{ml}$ in an organ bath, display more than $70 \%$ embarrassment of acetylcholine and/or $\mathrm{KCl}$ solution-induced reduction of isolated guinea- pig ileum. The rates of impulsion in the small intestine into male Sprague Dawley rats as it means of evaluate anti-diarrhoeal activity of the aqueous extracts of leaf of Psidium guajava using morphine like the standard drug for reference was measured [48]. Locomotor coordination can be improved by the ethyl acetate extract of guava fruit [49].

Ojewole 2008 examined anti-diarrheal activity of guava leaves extract in water provoked diarrhea in the rodents. This extract produces important protection to rats and the mice in opposition to castor oiled induced diarrhea. It inhibits the intestinal transit in rats. The activity of this extract is dose dependent. Atropine dose have significant anti motility effect due to which castor oil-induced diarrhea is inhibited. Loperamide dose significantly delays the onset of the castor oil-induced diarrhea. By comparison of animals it was noticed that intestinal fluid secretion is reduced significantly. Guava extract have anti diarrhoeal activity and it can be used for the treatment and prevention of diarrhaea [50]. Guava have significant antidiabetic and antidiarrhoeal activities in ethanolic extracts $[51,52]$.

\section{Anti-inflammatory activity}

Extract of guava in ethyl acetate can stop the germ infection and thymus production. It can act as anti-viral agent. It can enhance the mRNA expression. Guava can alter the heme oxygenase- 1 protein's work. And due to this reason, it can be used as anti-inflammatory agent for skin. Extract of guava in ethanol inhibit the lipopolysaccharide from manufacturing of nitric oxide. It suppresses the expression of E2. In this way it works as anti-inflammatory agent [53].

Extract in ethyl acetate has the ability to minimize the antigen. It can stop the release of the $\beta$-hexosaminidase 
with histamine into RBL-2H3 cells. Due to this reason the appearance of TNF- $\alpha$ and IL- 4 mRNA stops. In this way the antigen inhibits and IкB- $\alpha$ become spoil. Benzophenone and flavonoids are important compounds found in guava. These compounds are responsible for the histamine inhibition and nitric acid production [54].

Guava extract also show anti-nociceptive activity. It happened by acetic acid production. Phenol is an important compound which is present in guava and dependable for the anti-allergic and anti-inflammatory activity [55]. The dose of guava extracts are effective in liver damage inflammation and serum production [56].

\section{Antioxidant activity}

Antioxidants are molecules which retard the oxidation process. The oxidation reactions may produce free radicals which damage the cells by starting various chain reactions. Free radicals which damage the cells cause cancer and many other diseases. Antioxidants terminate the free radicals and stop the chain reactions. Examples of antioxidants include beta-carotene, lycopene, vitamins $\mathrm{C}, \mathrm{E}$, and $\mathrm{A}$ and other substances. Oxidative reaction is one of most important destructive reaction. Free radical's damage is responsible for a lot of disorders in human like nervous disorders, inflammation, debates and viral infections. When drugs are metabolized in body the free radicals are produced. Sometimes the environmental changes and hormones become the reason of free radical production. These free radicals are responsible for all the oxidation reactions [57].

Guava contains high amount of antioxidants and anti-providing nutrients which are essential not only for life but also help to control the free radical activities. It also have a variety of phytochemicals which are beneficial for human health like diabetes, obesity and high blood pressure. There are two common methods by which antioxidants neutralize free radicals that is DPPH and FRAP assay. Extracts of guava in water and organic solvents have a large quantity of antioxidants which can stop the oxidation reaction. The concentration of these compounds become high with the increase in concentration [58]. Pink guava also has a high antioxidant activity [59].

Guava is highly rich in antioxidants which are helpful in decreasing the incidences of degenerative diseases such as brain dysfunction, inflammation, heart disease, cancer, arteriosclerosis and arthritis [60]. In fruits, the most abundant oxidants are polyphenols and ascorbic acid. The polyphenols are mostly flavonoids and are mainly present in glycoside and ester forms [61]. The free elagic acid and glycosides of apigenin and myricetin and are found to be present in guava [62].

Guava extracts in organic solvent influence the sperm production. It can increase the sperm concentration due to the presence of antioxidants. Ethanolic extract can increase the sperm quality and quantity. So, it can be used for the treatment of infertile males. Leaves of guava also have high content of antioxidants which can be separated in extracts. Ascorbic acid an important antioxidant, is present in leaves in excess [58, 63]. Guava has a high content of protocatechuic acid, quercetin, ferulic acid, ascorbic acid, quercetin, gallic acid and caffeic acid which are important antioxidants. Some studies says that guava has radio-protective ability with antioxidant activity $[4,58]$.

DPPH method shows that the guava has remarkable antioxidantcontents and these antioxidants dose not damage the human neutrophils. Extracts in different solvents shows that antioxidant activity of guava depends upon phenolic compounds rather than flavonoids. Methanol and aqueous extraction shows maximum activity [64-66]. Ethanolic extract of guava shows low activity in all antioxidant assays like DPPH and FRAP assay [67]. Due to antioxidant activity of guava it can control the diabetes. It shows a significant diabetic control in mice [68].

Quercetin, quercetin-3-O-glucopyranoside and morin can be isolated from leaves. These compounds show the anti-oxidant activity. Quercetin has free radical balancing activity. Its reducing power is much higher than all other compounds. It is considered as most active and strong antioxidant in the leaves of guava $[69,70]$.

A comparison was made between the antioxidant properties of convection oven-dried and fresh guavas. Convection oven-drying was resulted to retain most of the total phenolic contents (TPC), ascorbic acid equivalent antioxidant capacity (AEAC) and ferric reducing power (FRP) assay of guava. However, the drying resulted in a significant decrease of AEAC, TPC and FRP [71].

The antioxidant contents and activities of two different varieties of guava fruit were assessed; the results were based on the ability to scavenge DPPH of the fruit extracts in $50 \%$ ethanol, to bind to $\mathrm{Fe}(\mathrm{II})$ ion and to reduce $\mathrm{Fe}(\mathrm{III})$ to $\mathrm{Fe}(\mathrm{II})$. The results were compared with similar analyses of several other local fruits like orange, water apple, sugar apple, star fruit, dragon fruit and banana. It was found that the guava fruit is relatively rich in antioxidants. It demonstrates higher primary antioxidant potential as compared to the other fruits e.g. orange, however it displays lower secondary antioxidant potential. When guava fruit is stored at at $4{ }^{\circ} \mathrm{C}$ then increase in ascorbic acid content has been observed. The total phenol and ascorbic acid contents are higher in non-peeled fruit as compared to the peeled fruit. The banana was suggested as a powerful secondary antioxidant, however, it is weaker than orange as a primary antioxidant [72].

The antioxidative potential of guava extracts has rendered a new therapeutic path against the various complications and diseases. Further investigations are required in 
this regard to find the actual mechanism involved in antioxidant and other pharmacological activities of guava [73].

\section{Conclusions}

Psidium guajava (guava) is well known tropic tree grown in tropic areas for fruit. It is found to be effective in diarrhea, dysentery, gastroenteritis, hypertension, diabetes, caries, pain relief, cough, oral ulcers and to improve locomotors coordination and liver damage inflammation. Its skin contains a lot of phytochemicals in intuits fruit which is rich in vitamins (A \& C), iron, phosphorus and calcium and minerals. The phenolic compounds in guava help to cure cancerous cells and prevent skin aging before time. The leaves contain many fungistatic and bacteriostatic agents and important oxidants. Its ethyl acetate extract contains quercetinwhich can stop the germ infection and thymus production. Guava possesses anti-viral, anti-inflammatory, anti-plaque, antinociceptive activity and anti-mutagenic activities. Due to these biological activities it is can be quite helpful for the preventions and treatments of diseases. Ethanolic extract of guava can increase the sperm quality and quantity and can be used for the treatment of infertile males.

\section{Abbreviations}

cm: Centimeter; E. coli: Escherichia coli; IL-4: Interleukin 4; KCl: Potassium chloride; mRNA: Messenger RNA; RBL: Rat Basophilic Leukemia cells; S. aureus: Staphylococcus aureus; TNF: Tumor necrosis factor

\section{Acknowledgements}

Not applicable.

\section{Funding}

There is no funding for review article.

\section{Availability of data and materials}

All data generated or analyzed during this study are included in this published article.

The links for guava fruit (i), leaves (ii), flowers (iii) and stem (iv) of Fig. 1 are given below:

(i) https://www.indiamart.com/proddetail/jumbo-guava-17296565155.html, https://homeguides.sfgate.com/long-guava-tree-full-grown-86015.html (ii) https://www.stylecraze.com/articles/how-are-guava-leaves-beneficial-foryour-hair/\#gref

(iii) http://www.plantsrescue.com/tag/common-guava/

(iv) http://www.cocobolotreefarm.com/plants/guava-chinese

\section{Authors' contributions}

SN Selection, arrangement and compilation of suitable material. SH Supervising the whole work. NN editing and formatting. MR, Relevant literature search. All authors read and approved the final manuscript.

\section{Ethics approval and consent to participate}

Not applicable; this is a review article.

\section{Consent for publication}

Not applicable; this is a review article.

\section{Competing interests}

The authors declare that they have no competing interests.

\section{Publisher's Note}

Springer Nature remains neutral with regard to jurisdictional claims in published maps and institutional affiliations.

\section{Author details}

${ }^{1}$ Department of Chemistry, Lahore Garrison University, DHA Phase VI, Lahore, Pakistan. ${ }^{2}$ Department of Home-Economics, Lahore Garrison University, DHA Phase VI, Lahore, Pakistan. ${ }^{3}$ Department of Chemistry, Government College University, Lahore, Pakistan. ${ }^{4}$ Department of Chemistry, School of Science, University of Management and Technology, Lahore 54770, Pakistan.

Received: 17 June 2018 Accepted: 2 November 2018

Published online: 12 December 2018

\section{References}

1. Dakappa SS, Adhikari R, Timilsina SS, Sajjekhan S. A review on the medicinal plant Psidium Guajava Linn. (Myrtaceae). J Drug Deliv Ther. 2013;3(2):162-8.

2. Nwinyi O, Chinedu SN, Ajani OO. Evaluation of antibacterial activity of Pisidium guajava and Gongronema latifolium. J Med Plants Res. 2008;2(8): 189-92.

3. Morton JF. Fruits of Warm Climates; 2004. p. 425-8.

4. Jiminez-Escrig A, Rincon M, Pulido R, Saura-Calixto F. Guava fruit (Psidium guajava L.) as a new source of antioxidant dietary fiber. J Agric Food Chem. 2001:49(11):5489-93.

5. Arima H, Danno G. Isolation of antimicrobial compounds from guava (Psidium guajava L .) and their structural elucidation. Biosci Biotechnol Biochem. 2002;66:1727-30.

6. Rouseff RL, Onagbola EO, Smoot JM, Stelinski LL. Sulfur volatiles in Guava ( Psidium guajava L .) Leaves: Possible defense mechanism. J Agric Food Chem. 2008:56:8905-10.

7. Das AJ. Review on nutritional, medicinal and pharmacological properties of Centella asiatica ( Indian pennywort ). J Biol Act Prod from Nat. 2011;1(4): 216-28.

8. Kumar KPV, Pillai MSN, Thusnavis GR. Seed extract of P sidium guajava as ecofriendly corrosion inhibitor for carbon steel in hydrochloric acid medium. J Mater Sci Technol. 2011;27(12):1143-9.

9. Rahim N, Gomes DJ, Watanabe H, Rahman SR, Chomvarin C, Endtz HP, Alam M. Antibacterial activity of Psidium guajava leaf and bark against multidrugresistant Vibrio cholerae. Jpn J Infect Dis. 2010:63:271-4.

10. Rai PK, Rai NK, Rai AK, Watal G. Role of LIBS in elemental analysis of Psidium guajava responsible for glycemic potential role of LIBS in elemental analysis of Psidium guajava responsible for glycemic potential. Instrum Sci Technol. 2007:35:507-22.

11. Mukhtar HM, Ansari SH, Bhat ZA, Naved T, Singh P. Antidiabetic activity of an ethanol extract obtained from the stem bark of Psidium guajava (Myrtaceae). Die Pharmazie. 2006:61:725-7.

12. Smith RM, Siwatibau S. Sesquiterpene hydrocarbons of fijian guavas. Phytochemistry. 1975;14(9):2013-5.

13. Khan MIH, Ahmad JA. Pharmacognostic study of Psidiurn guajuva L. J Med Plant Res. 1985:23(2):95-103.

14. Rueda FDMN. Guava (Psidium guajava L.). fruit phytochemicals, antioxidant properties, and overall quality as influenced by postharvest treatments. University of Florida: (MSc thesis); 2005.

15. Dweck AC. A review of guava (Psidium guajava); 1987.

16. Grover IS, Bala S. Studies on antimutagenic effect of guava (Psidium guajava) in Salmonella typhimurium. Mut Res. 1993;300:1-3.

17. Meckes M, Calzada F, Tortoriello J, Gonzalez JL, Martínez M. Terpenoids isolated from Psidium guajava hexane extract with depressant activity on central nervous system. Phyther Res. 1996;10(7):600-3.

18. Sanches NR, Aparício D, Cortez G, Schiavini MS, Nakamura CV, Prado B, et al. An evaluation of antibacterial activities of Psidium guajava (L.). Braz Arch Biol Technol. 2005:48:429-36.

19. Vernin G, Vernin E, Vernin C, Metzger J. Extraction and GC-MS-SPECMA data bank analysis of the aroma of Psidium guajaua L. fruit from Egypt. Flavour Fragr J. 1991;6:143-8.

20. Reyes MU, Paull RE. Effect of storage temperature and ethylene treatment on guava (Psidium guajava L.) fruit ripening. Postharvest Biol Tec. 1995; 5214(95):357-65

21. Yang X, Hsieh K, Liu J. Guajadial : An Unusual Meroterpenoid from Guava Leaves Psidium guajava. Org Lett. 2007;9:5135-8. 
22. Begum S, Hassan SI, Ali SN, Siddiqui BS. Chemical constituents from the leaves of Psidium guajava. Nat Prod Res. 2004;18(2):135-40.

23. Ogunwande IA, Olawore NO, Adeleke KA, Ekundayo O, Koenig WA. Chemical composition of the leaf volatile oil of Psidium guajava L. growing in Nigeria. Flavour Fragr. J. 2003;18:136-8.

24. Taylor P, Pino JA, Agüero J, Marbot R, Fuentes V, Pino JA, et al. Leaf oil of Psidium guajava L. from Cuba. J Essent Oil Res. 2001;13:61-2.

25. Fu HZ, Luo YM, Li CJ, Yang JZ, Zhang DM. Psidials A-C, three unusual meroterpenoids from the leaves of Psidium guajava L. Org Lett. 2010; 12(5):5135-8.

26. Deguchi Y, Miyazaki K. Anti-hyperglycemic and anti-hyperlipidemic effects of guava leaf extract. Nutr Metab (Lond). 2010;7:9.

27. Anand V, Manikandan KV, Kumar S, Pushpa HA. Phytopharmacological overview of Psidium guajava Linn. Phcog J. 2016;8:314-20.

28. Conde Garcia EA, Nascimento VT, Santiago Santos AB. Inotropic effects of extracts of Psidium guajava L. (guava) leaves on the Guinea pig atrium. Brazilian J Med Biol Res. 2003;36(5):661-8.

29. Rai PK, Mehta S, Watal G. Hypolipidaemic \& hepatoprotective effects of Psidium guajava raw fruit peel in experimental diabetes. Indian J Med Res. 2010;131:820-4.

30. Jaiarj P, Khoohaswan P, Wongkrajang Y, Peungvicha P, Suriyawong P, Sumal Saraya ML, et al. Anticough and antimicrobial activities of Psidium guajava Linn. Leaf extract. J Ethnopharmacol. 1999;67(2):203-12.

31. Joseph B, Priya RM. Phytochemical and biopharmaceutical aspects of Psidium guajava (L.) essential oil: a review. Res J Med Plant. 2011;5(4):432-42.

32. Limsong J, Benjavongkulchai E, Kuvatanasuchati J. Inhibitory effect of some herbal extracts on adherence of Streptococcus mutans. J Ethnopharmacol. 2004:92:281-9

33. Rattanachaikunsopon P, Phumkhachorn P. Contents and antibacterial activity of flavonoids extracted from leaves of Psidium guajava. J Med Plants Res. 2010;4(5):393-6.

34. Anas K, Jayasree PR, Vijayakumar T, Kumar PRM. In vitro antibacterial activity of Psidium guajava Linn. Leaf extract on clinical isolates of multidrug resistant Staphylococcus aureus. Indian J Exp Biol. 2008;46(1):41-6.

35. Nair R, Chanda S. In-vitro antimicrobial activity of psidium guajava I . Leaf extracts against clinically important pathogenic microbial strains. Braz J Microbiol. 2007;38:452-8.

36. Banu MS, Sujatha K. Antimicrobial screening of leaf extract of Psidium guajava and its isolated fraction against some pathogenic microorganisms. Drug Invent Today. 2012:4(3):348-50.

37. Gonçalves FA, Neto MA, Bezerra JNS, Macrae A, De SOV. Antibacterial activity of guava, psidium guajava linnaeus, leaf extracts on diarrheacausing enteric bacteria isolated from seabob shrimp, Xiphopenaeus kroyeri (Heller). Rev. Inst. Med. trop. S. Paulo. 2008;50(1):11-5.

38. Chen Y, Zhou T, Zhang Y, Zou Z, Wang F, Xu D. Evaluation of antioxidant and anticancer activities of guava. Int J Food Nutr Saf. 2015;6(1):1-9.

39. Puntawong S, Okonogi S, Pringproa K. In vitro antibacterial activity of Psidium guajava Linn. Leaf extracts against pathogenic bacteria in pigs. Chiang Mai Univ. J Nat Sci. 2012:11(2):127-34.

40. Samiha Kabir S, Jahan SM, Hossain MH, Siddique R. Apple, guava and pineapple fruit extracts as antimicrobial agents against pathogenic bacteria. Am J Microbiol Res. 2017;5(5):101-6.

41. Adhami VM, Khan N, Mukhtar H. Cancer chemoprevention by pomegranate: laboratory and clinical evidence. Nutr Cancer. 2009;61(6):811-5 8.

42. Al-Zoreky NS. Antimicrobial activity of pomegranate (Punicagranatum L.) fruit peels. Int J Food Microbiol. 2009;134:244-8.

43. Afroja S, Falgunee FN, Jahan MK, Akanda KM, Mehjabin S, Parvez GMM. Antibacterial activity of different citrus fruits. Specialty journal of medical research and health. Science. 2017;2(1):25-32.

44. S M, Hegde AU, N.S S, T.R PK. Antimicrobial activity of Citrus Sinensis and Citrus Aurantium Peel extracts. J pharm sci innov. 2014;3(4):366.

45. Venkatesan N, Thiyagarajan V, Narayanan S, Arul A, Raja S, Kumar SGV, Rajarajan T, Perianayagam JB. Antidiarrheal potential of Asparagus racemous wild root extracts in laboratoire animals. J Pharm Pharmaceut Sci. 2005;8:39-45.

46. Teixeira RDO, Camparoto ML, Mantovani MS. Assessment of two medicinal plants, Psidium guajava L. and Achillea millefolium L., in in vitro and in vivo assays. Genet Mol Biol. 2003;555:551-5.

47. Vieira RHSF, Rodrigues DP, Gonçalves FA, Menezes FGR, Aragoo JS, Sousa OV. Microbicidal effect of medicinal plant extracts (Psidium guajava linn. And Carica papaya linn.) upon bacteria isolated from fish muscle and known to induce dirrhea in children. Rev Inst Med trop S Paulo. 2001;43:145-8.
48. Tonal L, Kambu K, Mesial K, Cimanga K, Totte J, Vlietinck AJ. Biological screening of traditional preparations from some medicinal plants used as antidiarrhoeal in Kinshasa, Congo. Phytomedicine. 1999;6(1):59-66.

49. Shaheen HM, Ali BH, Alqarawi AA, Bashir AK. Effect of Psidium guajavo leaves on some aspects of the central nervous system in mice. Phyther Res. 2000;14(2):107-11.

50. Ojewole J, Awe EO, Chiwororo WDH. Antidiarrhoeal activity of Psidium guajava Linn. (Myrtaceae) leaf aqueous extract in rodents. J Smooth Muscle Res. 2008;44(6):195-207.

51. Mazumdar S, Akter R, Talukder D. Antidiabetic and antidiarrhoeal effects on ethanolic extract of Psidium guajava (L.) bat. Leaves in Wister rats. Asian Pac J Trop Biomed. 2015;5(1):10-4.

52. Birdi T, Daswani P, Brijesh S, Tetali P, Natu A, Antia N. Newer insights into the mechanism of action of Psidium guajava L. leaves in infectious diarrhoea. BMC Complement Altern Med. 2010;10:33.

53. Jeong S, Cho SK, Ahn KS, Lee JH, Yang DC, Kim J. Anti-inflammatory effects of an ethanolic extract of guava (Psidium guajava $L$.) leaves in vitro and in vivo. J Med Food. 2014;17(6):678-85.

54. Matsuzaki K, Ishii R, Kobiyama K. New benzophenone and quercetin galloyl glycosides from Psidium guajava L. J Nat Med. 2010;64:252-6.

55. Denny C, Melo PS, Franchin M, Massarioli AP, Bergamaschi KB, Alencar SM De, et al. Guava pomace : a new source of anti-inflammatory and analgesic bioactives. 2013

56. Roy CK, Kamath JV, Asad M. Hepatoprotective activity of Psidium guajava Linn. leaf extract. Indian J Exp Biol. 2006;44(4):305-11.

57. Masuda T, Inaba Y, Maekawa T, Takeda Y, Yamaguchi H, Nakamoto K, Kuninaga H, Nishizato S, Nonaka A. Simple detection method of powerful antiradical compounds in the raw extract of plants and its application for the identification of antiradical plant constituents. J Agric Food Chem. 2003:51:1831-8

58. He Q, Venant N. Antioxidant power of phytochemicals from Psidium quajava leaf. J Zhejiang Univ Sci A. 2004;5(6):676-83.

59. Musa KH, Abdullah A, Jusoh K, Subramaniam V. Antioxidant activity of pinkflesh guava (Psidium guajava l.): effect of extraction techniques and solvents. Food Anal Methods. 2011;4:100-7.

60. Feskanich D, Ziegler RG, Michaud DS, Giovannucci EL, Speizer FE, Willett WC, Colditz GA. Prospective study of fruit and vegetable consumption and risk of lung cancer among men and women. J Natl Cancer Inst. 2000:92:1812-23.

61. Fleuriet A, Macheix JJ. Phenolic acids in fruits and vegetables. In C. A. RiceEvans \& L. packer, flavonoids in health and disease. New York: Marcel Dekker Inc.; 2003.

62. Koo MH, Mohamed S. Flavonoid (myricetin, quercetin, kaempferol, luteolin and apigenin) content of edible tropical plants. J Agri Food Chem. 2001;49:3106-12

63. Thaipong K, Boonprakob U, Cisneros-zevallos L, Byrne DH, Pathom N. Hydrophilic and lipophilic antioxidant activities of guava fruits. Southeast Asian J Trop Med Public Health. 2005;36:254-7.

64. Fernandes MRV, Azzolini AECS, Martinez MLL, Souza CRF, Oliveira WP. Assessment of antioxidant activity of spray dried extracts of psidium guajava leaves by dpph and chemiluminescence inhibition in human neutrophils. Biomed Res Int. 2014;2014:382891 Article ID 382891.

65. Seo J, Lee S, Elam ML, Johnson SA, Kang J, Arjmandi BH. Study to find the best extraction solvent for use with guava leaves (Psidium guajava L.) for high antioxidant efficacy. Food Sci Nutr. 2014;2:174-80.

66. Santhoshkumar T, Rahuman AA, Jayaseelan C, Rajakumar G, Marimuthu S, Kirthi AV, Valayutham K, Thomas J, Venkatesan J, Kim S. Green synthesis of titanium dioxide nanoparticles using Psidium guajava extract and its antibacterial and antioxidant properties Green synthesis of titanium dioxide nanoparticles using Psidium guajava extract and its antibacterial and antioxidant properties. Asian Pac J Trop Biomed. 2014;7:968-76.

67. Vijayakumar K, Anand AV, Manikandan R. In vitro antioxidant activity of Ethanolic extract of Psidium guajava leaves. Int J Res Stud Biosci. 2015; 3(5):145-9.

68. Manikandan $\mathrm{R}$, Anand AV. Evaluation of antioxidant activity of psidium guajava Linn . In streptozotocin - induced diabetic rats. Free Radicals Antioxid. 2016;6(1):72-6.

69. Nantitanon W, Okonogi S. Comparison of antioxidant activity of compounds isolated from guava leaves and a stability study of the most active compound. Drug Discov Ther. 2012;6(1):38-43.

70. Soman S, Rauf AA, Indira M, Rajamanickam C. Antioxidant and Antiglycative potential of ethyl acetate fraction of Psidium quajava leaf extract in Streptozotocin-induced diabetic rats. Plant Foods Hum Nutr. 2010;65:386-91. 
71. Siow LF, Hui YW. Comparison on the antioxidant properties of fresh and convection oven-dried guava (Psidium guajava L.). Int Food Res J. 2013; 20(2):639-44.

72. Yan $L Y$, Teng $L T$, Jhi TJ. Antioxidant properties of guava fruit: comparison with some local fruits. Sunway Academic Journal. 2006;3:9-20.

73. Manikandan R, Vijaya Anand A. A Review on Antioxidant activity of Psidium guajava. Res J. Pharm. and Tech. 2015;8(3):339-42.

Submit your manuscript to a SpringerOpen ${ }^{\circ}$ journal and benefit from:

- Convenient online submission

- Rigorous peer review

- Open access: articles freely available online

- High visibility within the field

- Retaining the copyright to your article

Submit your next manuscript at $\boldsymbol{\sim}$ springeropen.com 